\title{
Urban Square: Stage for Improving Social Life: Comparing Characteristics of Toop-Khane Square and Naghsh-E Jahan Square, Iran
}

\author{
Nastaran* \\ Department of Anthropology, University of Tennessee, USA
}

Submission: March 06, 2017; Published: September 25, 2017

*Corresponding author: Nastaran, Department of Anthropology, University of Tennessee, USA, Email: nabdoli@vols.utk.edu

\begin{abstract}
Now a days there has been attention to the interrelation between built environment and people; as people are inseparable parts of environment. In this paper, the built environment refers to manmade places and mostly urban spaces. Cities are dynamic places, urban spaces with high potential can encourage presence of people. Among urban open spaces, squares can provide the opportunity to improve social life in cities. In this paper, I will compare two different squares in Iran, Toop-Khane which is the result of modern trends and Naghsh-e Jahan which is a traditional square. I will review the structural form of these squares and assess their role in urban life.
\end{abstract}

\section{Introduction}

Cities as living entities and dynamic systems undergo changes in function, body and its role in the society due to contemporary demands of people. Considering the fact that people are an integral part of cities, would likely help understanding the necessity to improve their presence in the built environment; open spaces provide residents the chance of great urban experience if they have been designed in a way to address and consider peoples' expectations. Urban spaces are public spaces in cities, and urban square is a public space. Urban open spaces are realms for people to be a part of city life.

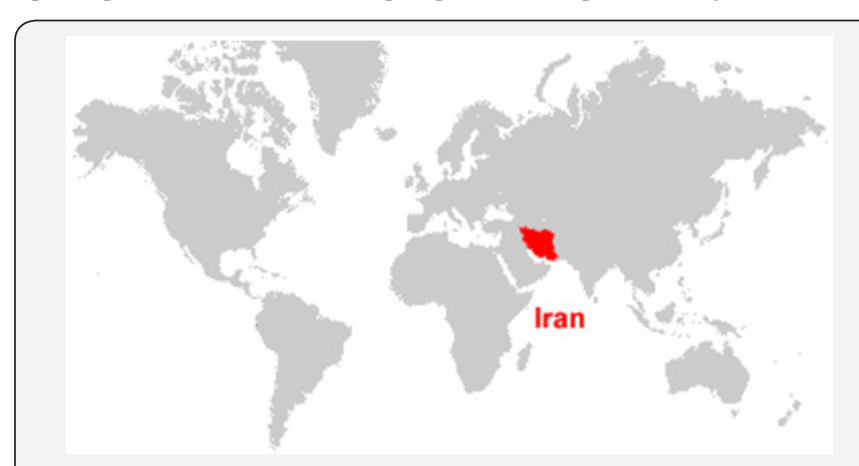

Figure 1: Location of Iran in world.

This can be achieved through considering open spaces in urban setting as places for public multi-purpose activities, leisure activities, events and ceremonies.“Urban open spaces has their meanings from presence and activities of people" Soltanian \& Mohammadi [1] this can be achieved if researchers explore lifestyles, attitudes and attributes to urban spaces in cities that leads to better design of such places. Researches indicate the role of urban spaces in different aspects of residents' life Figure 1. "Urban open spaces have been critical sites of cultural, political, and economic life from early civilizations to the present day" Stanley [2] Urban open space can refer to as "open areas for public use that are situated within the urban fabric of a city" Holub [3] it also can be considered as "any urban ground space, regardless of public accessibility, that is not roofed by an architectural structure" Stanley [2]. Here, I will apply the word urban open spaces with public accessibility Figure 2.

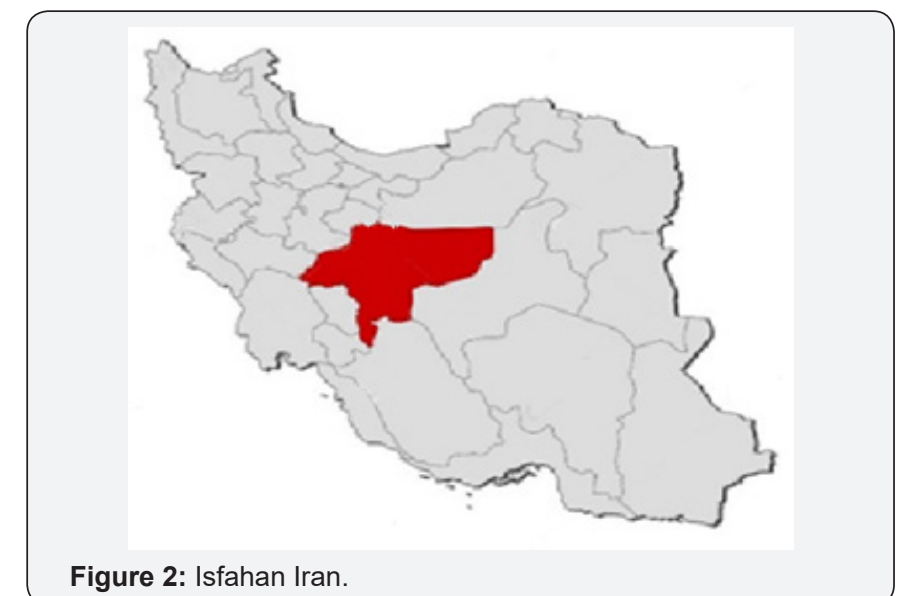

Various factors associated to interactions in public space. Mehan [4] categorized the most important ones as follow: Urban spaces include a wide range of places like parks, plazas, squares, streets etc. In this sense, urban open spaces are important parts of cities which "boost the quality of city life" Pakzad [5]. Square, as an urban space, is one of the most important key components 
of city. Therefore, considering special characteristics for square would help providing great city experience for residents; as Zakariya [6] found out that "square designs ought to meet evolving social, physical and environmental needs to cater for future requirements and lifestyles" Zakariya [6].

Researches indicated that square has an important role in social life in today's life as it has in the past. Among various urban open spaces, squares are one of the key elements of city structure Two of the key elements of urban places according to Krier [7] are streets and squares with high impact on social life. Square refers to a unified, welcoming and collective boundary with social dynamics Pakzad [5]. Meydan is the translation of square in Farsi and it means "deep inside the city and a place for gathering" Pirnia [8]. Square and its related elements physically are essential components of city context and texture, which provide social interaction. Krier believes that square might be one of the first human innovations to use urban spaces and "it was produced by grouping of houses around an open space" Krier [7]. Square can be large or small, it can have any shapes and it can function at different scales, but with any characteristic they should enhance interaction and enhance social life. As Zakariya [6] believed good squares are sociable places, therefore they can enhance the social life.

The general characteristics of every square are similar, in different context it might differ based on local and cultural preferences. Here, I provided a list of characteristics that researches have come across for squares. The form of the square, type of the square, sustainability of urban square, connecting rather than dividing, a place for communication and continuity of social life, facilitate people's diverse activities, asocial place to interact and comfort (not necessarily interact with strangers, a place tostay, pause, sit and enjoy), flexible space for public use for various ceremonies, events, activities for example, NaghsheJahan square which I will explain in details later is an example of a flexible urban space that people use it for celebrating new year, religious purposes, parades, political movements encouraging pedestrians to walk, location and the context, facilities and amenities (people should feel safe at the square), optional activities, landscape, connection between people and its surrounding, relationship between social and cultural context to public space, accessibility Zakariya [6], Zhai [9], Abidin [10] \& Krier [7].

Lynch believed that "an urban square is the activity focus in the center dense of urban areas, enclosed by high density structures and surrounded by streets or in contact with them. It contains features meant to attract groups of people and to facilitate meanings" Lynch [11]. Therefore, it is essential to investigate the characteristics of square when revitalizing or creating urban squares. As it is discussed, the role of urban squares is highly important in reinforcing social life. Squares can meet needs and expectations of residents, such places give identity to cities. These kind of places functions as a relief for urban life that people can escape from hectic of urban life and enjoy their time; in this sense, it has psychological effects and can likely improve public health, as WHO claimed that urban settings have a direct health impact on people (WHO 2010). Since they are aimed to serve public as multi-use destination, investigating on these places would more likely to boost city experience.

Probably, from the time that cities shaped, people had such place for gathering; humankind as a social creature tends to interact with others and this happened through gatherings; but urban square as it is known today can be traced back to Europe. Square was born in Europe. European cities are characterized by public squares and they provide a rich and encouraging environment for people. One of the main elements of ancient Greece was 'Agora' which means place for people to gather and talk" Liu [12]. Historical function of square was engaging public to interact with the environment. "The Agora was an open place in the city center where political, social and economic activities took place" Memluk [13].

This indicate the flexibility and the main characteristic of urban squares that should set the stage to facilitate activities and to welcome different events. Similarly, 'forum' in Rome had the same purpose _a gathering place but it situated more activities within itself and was more formal Sitte [14]. As it is discussed, urban squares historically enhanced social life and it is found they have the same impact in modern world; as a part of built environment it is an integral part of social life Rapaport [15].There is no doubt that urban squares exist as a responsive approach to society. According to Abbasian, square have different uses over time based on time and place. He mentions that "in past, most economic activity and various religious activities social an governmental have been done in open space while nowadays it is more for walking, refreshment , eating, drinking, shopping and watching surrounding" Abbasian [16].

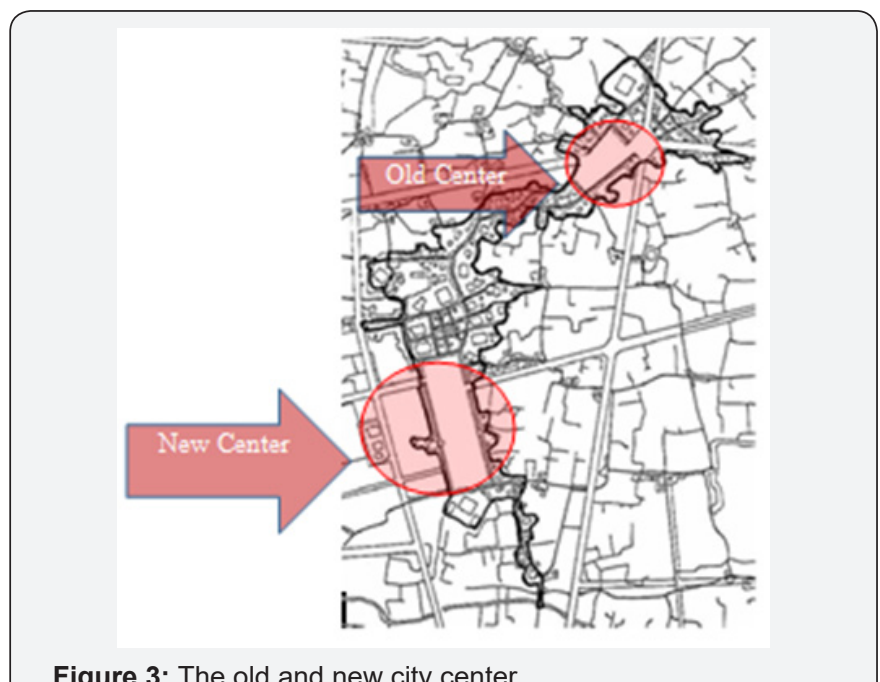

Figure 3: The old and new city center.

The concept of urban square in Iran is not as rich as it is in Europe, but there still exist number of squares that embodied the concept of square in urban setting Figure 3. The square in Iran changed over time. The changes that happened in squares 


\section{Global Journal of Archaeology \& Anthropology}

was influenced by social, political and religious forces that were dominant in specific eras, Mehan (2016) indicated that squares are scenes of urban transformation Table 1 . The transition of square in Iran ranges from a place that all main buildings were

Table 1

\begin{tabular}{|c|c|}
\hline \multicolumn{2}{|c|}{ Influencing Factors on Social Interactions in Public Spaces Mehan [4] } \\
\hline Threatening Factors & Reinforcing Factors \\
\hline congestion & Population density \\
\hline Failure to comply with privacy & Spatial proximity \\
\hline Illegal activities and vendors & Cozy spaces \\
\hline Irregularities in the organization and design & Cultural and artistic activity \\
\hline Elements & Natural elements and landscape \\
\hline Motion spaces & Stop and pause space \\
\hline
\end{tabular}

As Khodaakhshi [19] discussed, the square in Iran experienced three period of changes, first in Seleucid era which square was mostly use for showing government power, the second change came with Islam which changed the spatial structures of squares and, the third one is within modernity changed forms of cities in Iran and it also had impacts on square structure which indirectly changed the role of square in urban and social life Kodabakhshi [19], Tafahomi [18]. Here, the articles compares two urban square in Iranian context from traditional and from modern era. Naghsh-e-Jahan square is the only urban space which remained almost the same besides some changes in its role and some physical elements.

The foundation of this square dated back to 1598 and 1629 . It is square shape with width of $156 \mathrm{~m}$ and length of $510 \mathrm{~m}$. The square is two floor arcades, which the first floor are mostly shops. Until Pahlavi era the body of square remained intact. The direction of the square is probably because of the placement of surrounding setting at the time of building the square; this characteristic is still a main factor in building and constructing urban spaces since it should be adjusted to the city texture and setting. As mentioned earlier, square should be flexible and play a multi-use destination for people. Naghsh-e-Jahan, from the time of construction welcomed different activities, according to Tavassoli [15] the square was used as a market place that attracts lots of people to buy and sell things. It was also a place for ceremonial events that the government hosted. It was designed to connect this center to the old square of Isfahan.

The four main elements of the square includes Imam (Shah Safavi) mosque, Sheikh Lofollah mosque, AliQapu palace and Qeisarye portal. The Naghsh-e-Jahan square with these four elements include all governmental, social, cultural, religious, and business characteristics. This square was built upon the order of Shah Abas Safavi who moved the capital from Qazvin to Isfahan. At his era, Islam was the primary religion of Iran; building two mosques around the square is a proof of influenced structure by Islam. The square used for multiple purposes like: military maneuvers, shooting competitions, javelin throwing, horse riding, wicket, and peoples gathering in front of Ali Qapu to see the king (Shah) Tavassoli [15]. The entranced of Shah Safavi interaction to a place for announcing governmental declarations, showing glory and prestige of the ruling government etc. Habibi [17], Tafahomi [18] \& Khodabakhshi [19]. placed around square in the center for cultural and economic

mosque is placed in the length of the square and Ali Qapu palace and Sheikh Lotfollah palace are placed in front of each other Figure 4. Sheikh Lotfollah mosque was built for Sheikh Lotfollah who was close to the king in order to teach religious studies in the mosque.

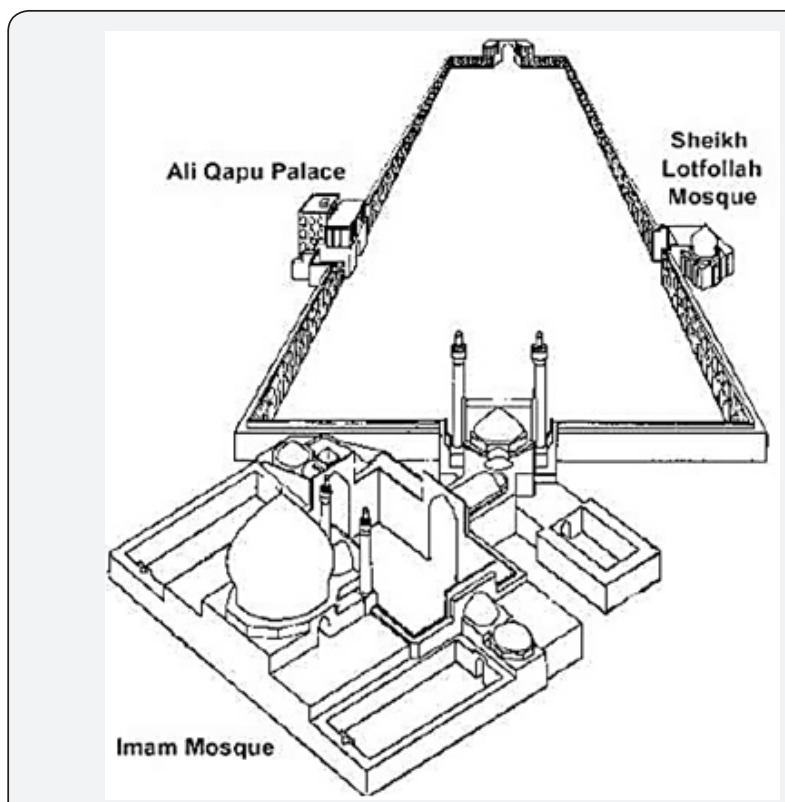

Figure 4: The four main elements surrounding Naghsh-e-Jahan Square.

As it can be seen, the spatial structure of the square is founded upon demands of especial era. Naghsh-e-Jahan square remained the same almost in its structure, besides little changes like planting buttonwood trees during Pahlavi era which were removed years after plantation and adding a pool to the square by the last queen of Iran in order to make balance in the square; nowadays the square is mostly a tourist destination and a pleasant place with high capability to be used by city dwellers, the structure has been conserved very well. People use this place for walking, shopping, leisure time, it also a good place for different activities and ceremonial events. Naghsh-e-Jahan square is one of the world's successful urban squares that still plays an important role in city life experience. 
Many year after building Naghsh-eJahan square, in 1916 Tehran introduced new concepts and approaches to square and street. At this time, square is not a place for showing social behaviors, it is mostly a place for memories and feeling attached to a place.

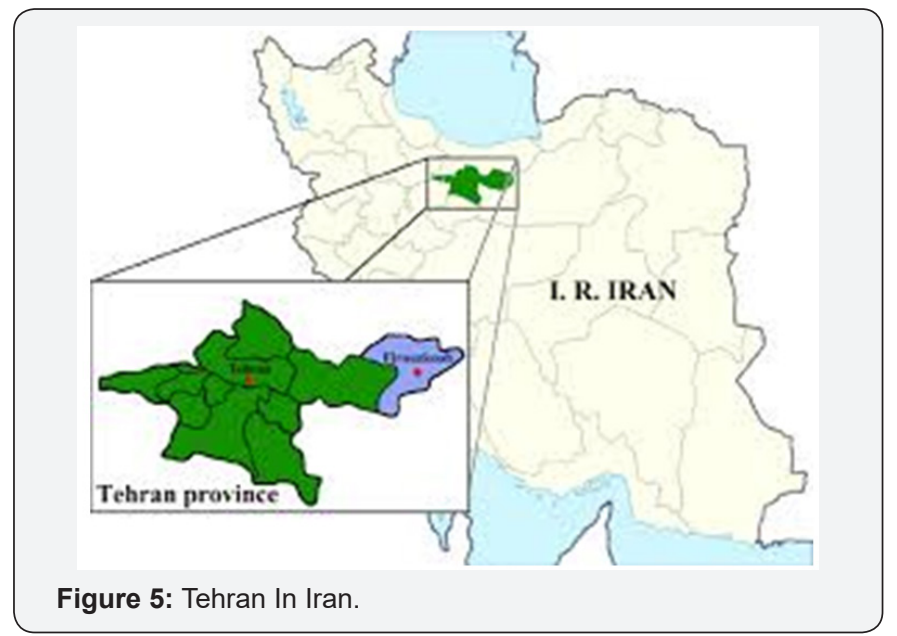

With this new approach, Toop-Khane square was built with modern elements to be the first modern square in Iran. "ToopKhane square was built in 1904 (1281 lunar year) in two floors, square-shaped, $220 \mathrm{~m}$ long and $110 \mathrm{~m}$ wide in north of citadel". Toop-Khane square avoid following spatial structure past and replaced surrounding common elements of square with buildings who echo down the new era of modernism. This space functioned as military, public and governmental square (Mehan 2016), it was also promising of the new age to improve the use of automobiles, but throughout changes nowadays it functions as a traffic node and modern commercial and administrative center (Barati) [20]. The change in characteristic and role of Toop-khane square shows the power dominant relation in urban spaces, once it was a space for governmental power and now the role changed to traffic node Figure 5 . To better understand the changes, the four periods of structural change will be discussed:

As it is shown in Figure 6, Toop-Khane square with buildings like telegraph house, bank and post office was built as a sign of modernism at that time. Streets connecting to the square through designed portals which reflect the dominant architecture style of the time and would be considered as ties with the traditional form and style of square in Iran. An important design aspect in urban spaces and especially in urban squares is to define the place to reflect enclosure. These designed portals give sense of unity and make the square a distinctive place from adjunct areas. These portals signal entering a special place that improve the identity of the place. As mentioned earlier, one of the main functions of Toop-Khane square was military uses, and it was also a place for gatherings and leisure activities.

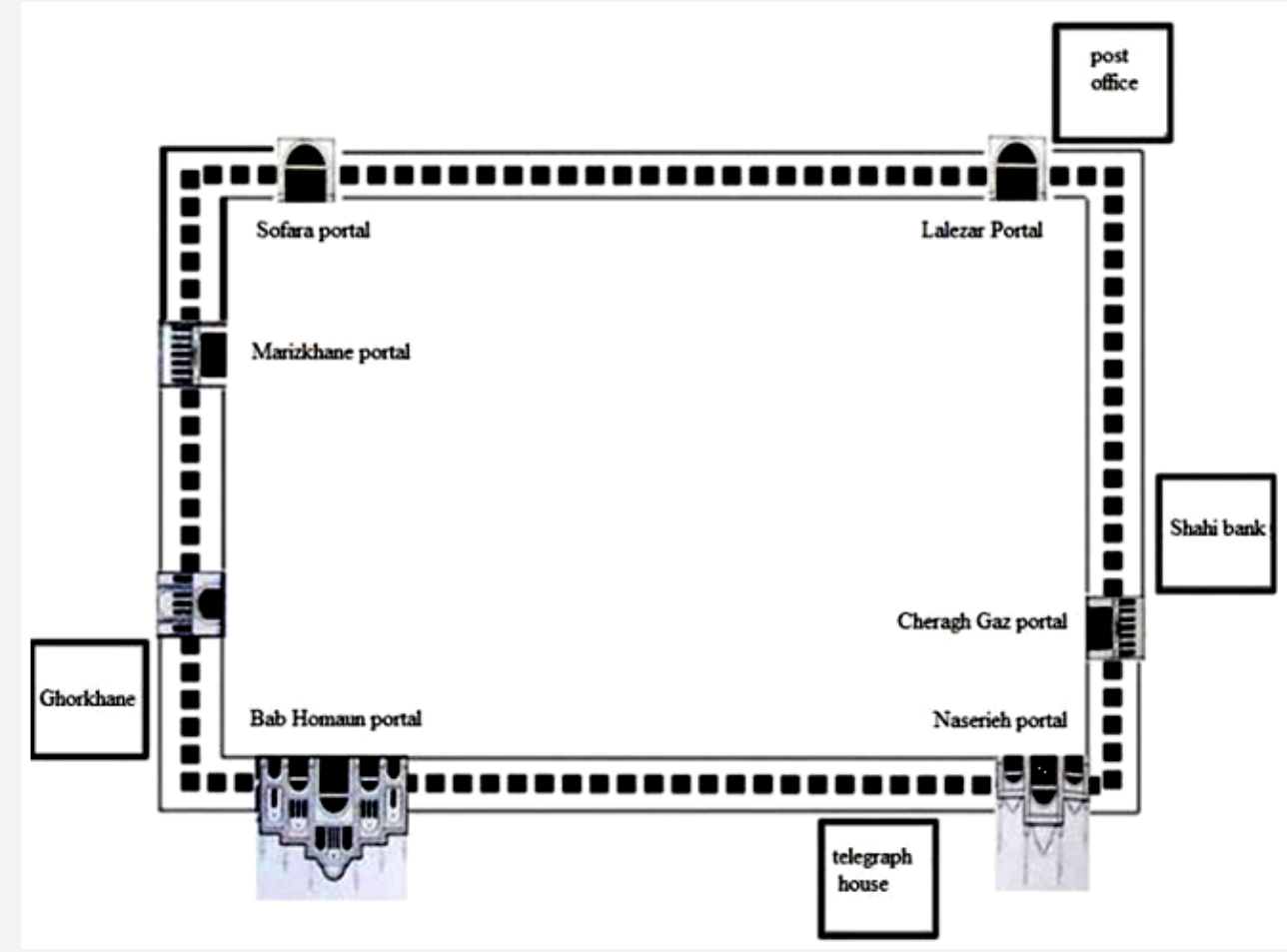

Figure 6: Toop-Khane square with modern elements. Khodakakhshi [19] .

The first period of changes Figure 7 happened by ruining the gates in order to facilitate vehicle traffic to the square. Although ruining gates changes the structure and image of the square, it still functioned as a lively public space [21]. At this time a new military building (Nazmie building) was build which reinforce the military role of the square. Changes that happened during 1921-1941 Figure 8 can be considered as the second wave of changes. At this time, widening the connecting streets to square was the priority in order to facilitate traffic. This approach was the starting point of collapsing the identity of the square 
that replace car dominance instead of people presence. During this period, three other business buildings were build which destroyed the form of square. Priority of traffic discouraged the presence and social life and set the stage for a decaying process in social life of the square.

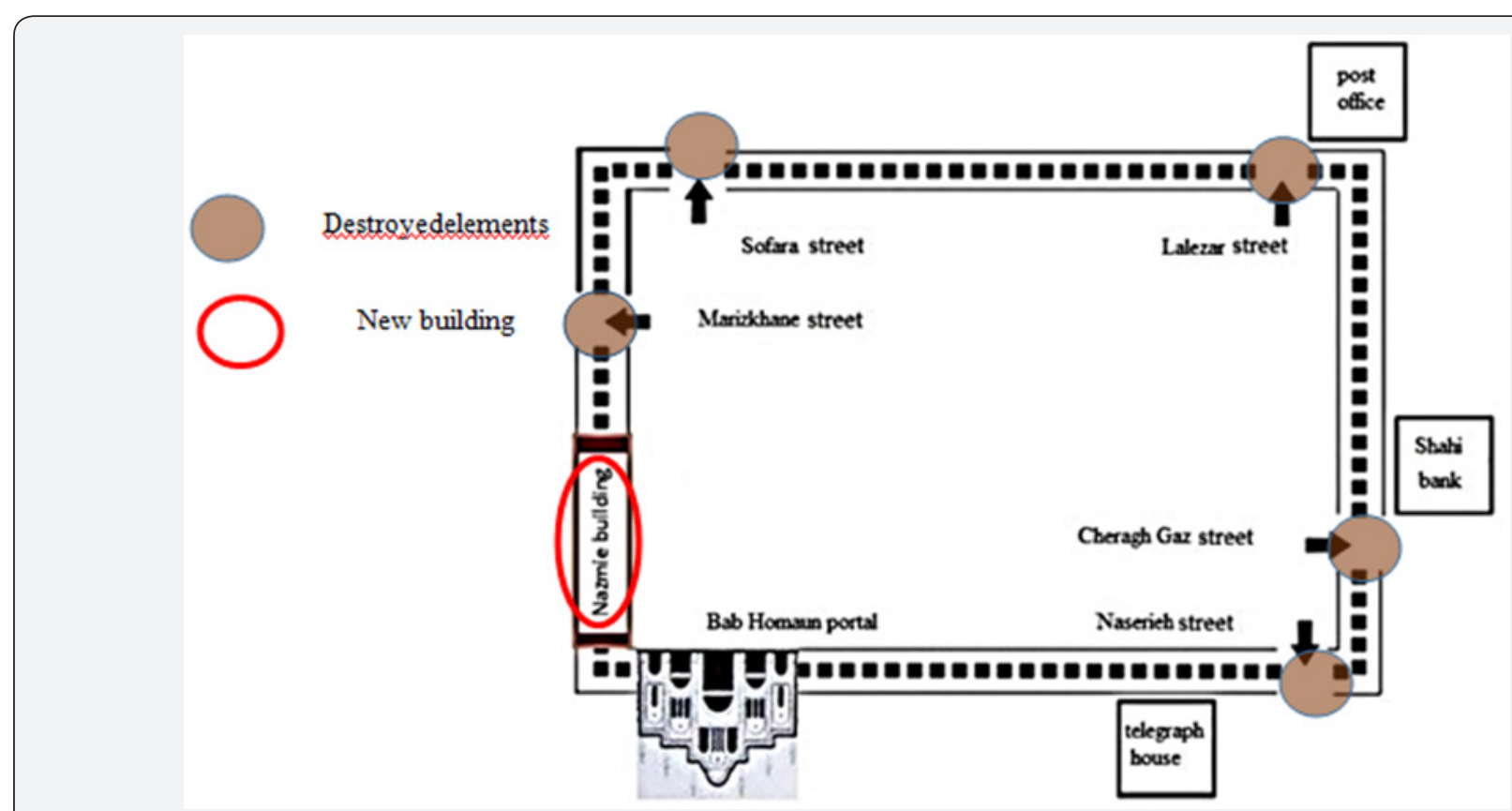

Figure 7: Changes of the first period in Physical elements of Toop-Khane square Khodakakhshi [19].

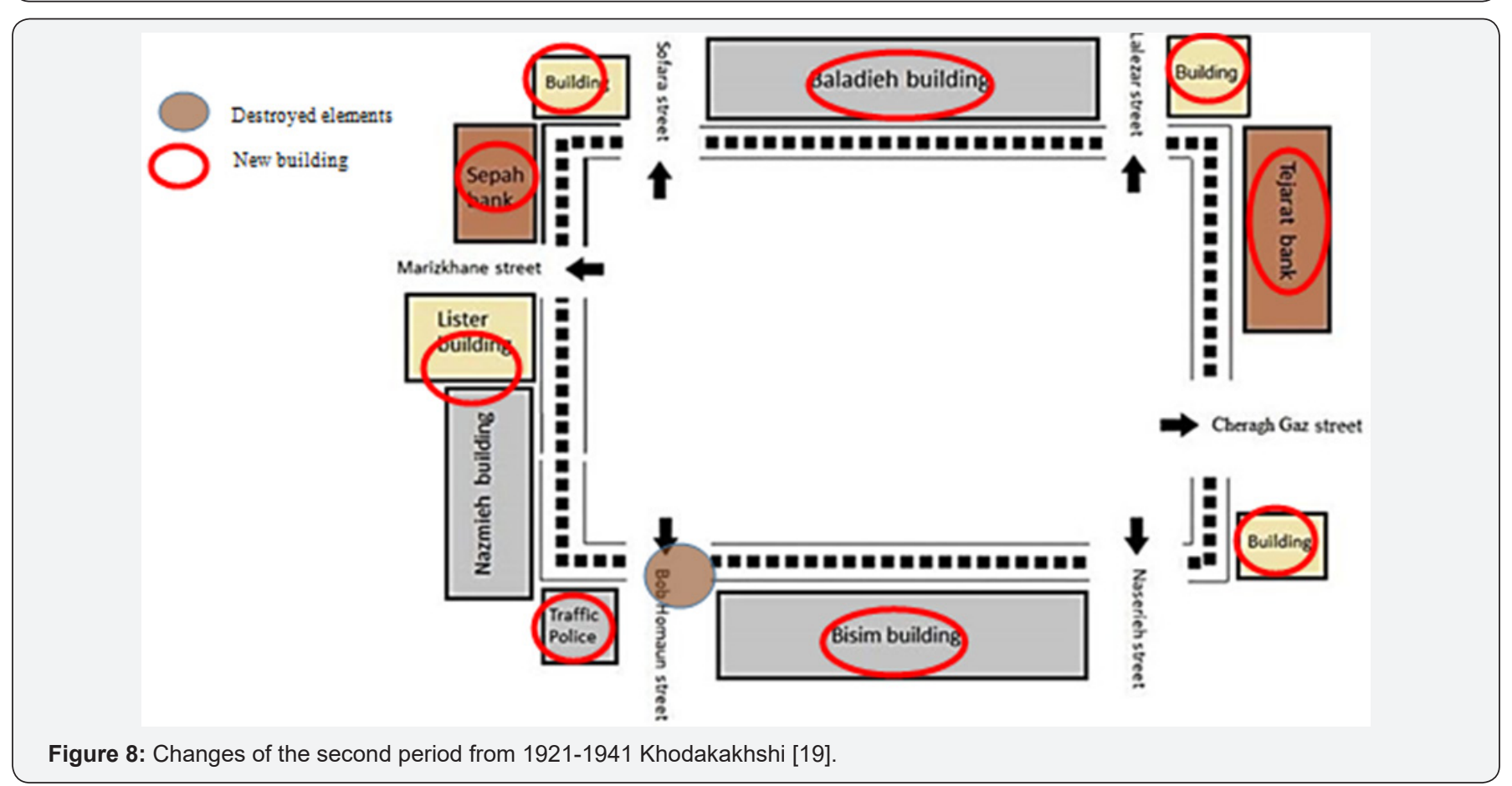

The third period of changes continues with destroying some buildings and replacing new ones. As it is seen in Figure 9, new street connect to square to improve traffic pass way and transforming the square to a gridlock of automobiles. Fourth period of changes coincides with the Islamic regime, at this time the spatial structure of the square changed substantially. At this time, locating subway stations in the square maintained the traffic role of the square and as Khodabakhshi indicates: "with the destruction of buildings, widening of streets and the growth of transportation vehicles, this square lost its identity, and the remaining buildings around the square have no harmony and consistency". Nowadays, Toop-Khane has lost the main identity as a place for social interaction because it lacks the vital criteria of urban square Figure 10. 


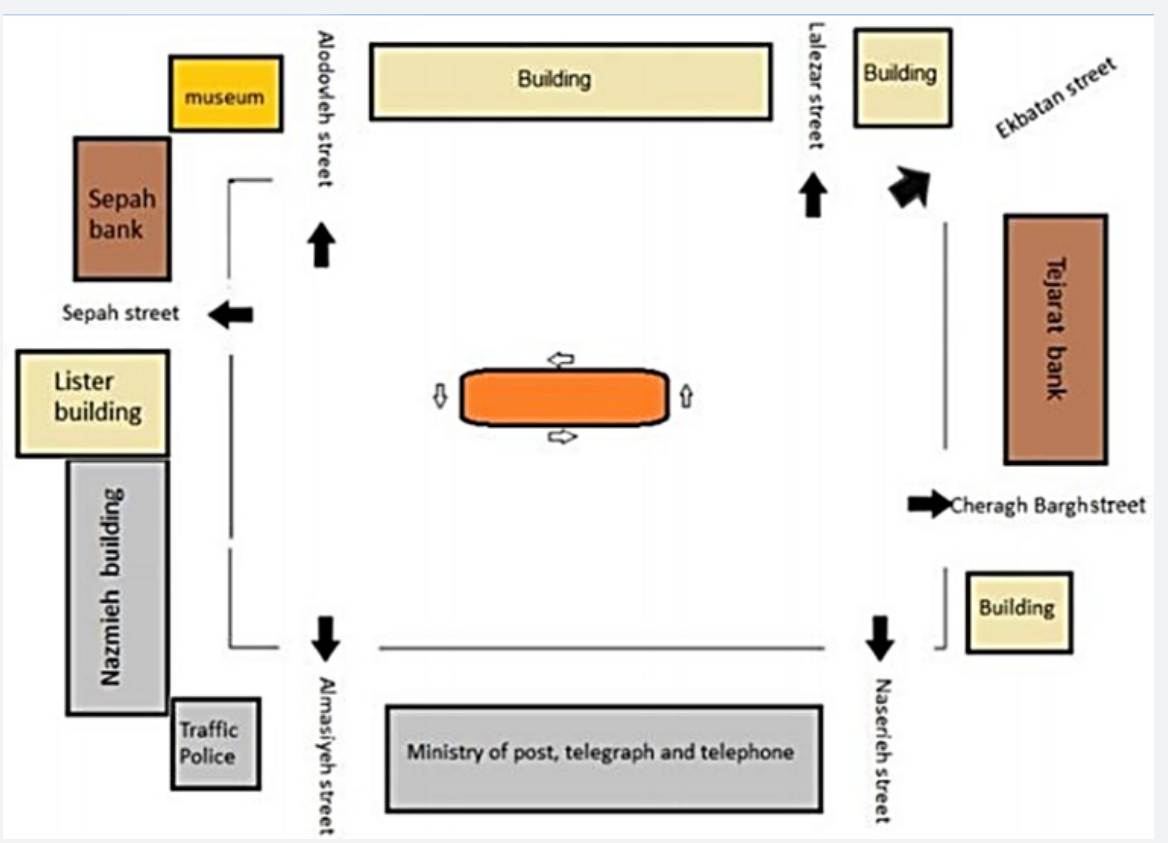

Figure 9: Changes between 1961 and Islamic revolution Khodakakhshi [19].

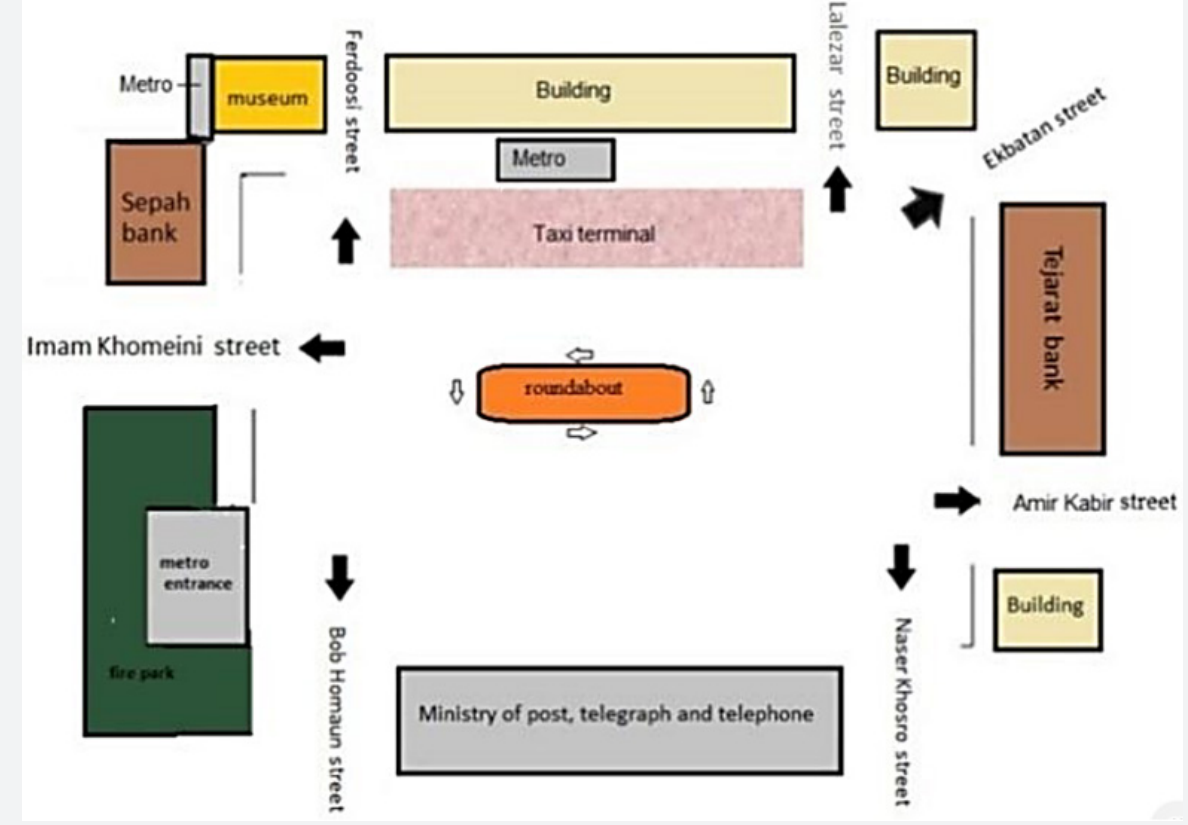

Figure 10: Present Toop-Khane square Khodakakhshi [19].

As explained throughout the paper, there can be definite characteristic for urban squares as public places Table 2. In urban areas, it is important to create new urban spaces with the purpose of enhancing social life. It should be noted that, revitalizing existing urban spaces and specifically urban squares can be the first option rather than creating new places. In these case studies, the characteristic of two different urban squares were discussed. Toop-Khane square has number of valuable potentials that pave the way to boost social life and people presence. In such places that suffer from lack of space management and changed in response to the dominant demand of their time is likely to function as highly encouraging interactive places if spatial design and structure follow some rules and regulations and make attempts to be beneficial for society and for people.

The vast are of Toop-Khane is highly valuable since it is located in the old texture of Tehran that the land price is significantly high. Through designing approaches, the ToopKhane has the potential to function as social place. It is suggested that: United design for facades with specific difference in details, lighting design to improve the aesthetic aspects of the square 
and to also provide a safe environment late at night, limit traffic access to square, increase green spaces and seating facilities, remove visual barriers if possible, moving taxi terminal to another place in order to reduce automobile presence, place elements and monuments which reflect the historical and cultural background of square, place informative elements on the history and changes of the square etc. These are some design strategies that of accompanies by historic and cultural identity of the square. The guideline that I plan to work on, include strategies and approaches that help improve the square identity considering modern changes and the possibility of increasing social life in the square.

Table 2

\begin{tabular}{|c|c|}
\hline Naghsh-E Jahan Square & Toop-Khane Square \\
\hline Multi functionality is possible due to the vast area of square & Vast area for public presence \\
\hline Traffic is limited to one side of the square, safety and amenity & Traffic dominance faded the square identity \\
\hline Pedestrian dominance over traffic & Lack of safety for pedestrians \\
\hline Attractive activities: riding on stagecoach around the square & Inference of pedestrians with moving vehicles \\
\hline Historic buildings functions as tourist attraction & Lack of unity in the body of square \\
\hline Imam square continues its religious role and it is used for prayers & Lack if integration in building facades \\
\hline Shops and exchange stores improve public presence & Illegal activities and vendors in the square \\
\hline Facilities like seating areas is encouraging & Lack of accessibility to the center of the square \\
\hline $\begin{array}{l}\text { New buildings close to square comply with historic preservation standards, it includes } \\
\text { specific rules on architecture to prevent exotic styles }\end{array}$ & Visual barriers to buildings \\
\hline & Inadequate facilities for seating \\
\hline
\end{tabular}

Built environment include manmade constructions, human kind reflect $\mathrm{s}$ to the built environment; in this way the effect of built environment on human is dramatically important. Urban spaces encourage people presence in cities. Among urban paces, urban squares are one of the key elements in cities with impact on social life and public health. Therefore, creating and improving urban square identity and characteristic is a must for researchers and scholars who are involved with human being. Providing a guideline for enhancing square characteristic will help residents to better integrate in society. Therefore, it is suggested that make people the priority in planning urban spaces that will guarantee interactive and dynamic behavior in city context.

\section{References}

1. Soltanian F, Atefeh M (2015) Study of characteristics of urban public open spaces based on social interaction (Case study: Salavatabad's 3-kilometer route). European Online Journal of Natural and Social Sciences 4(3): 553-564.

2. Stanley B, Barbara S, Katrina J, Michael S (2012) Urban open spaces in historical perspective: a transdisciplinary typology and analysis. Urban geography 33(8): 1089-1117.

3. Holub K (2011) Encouraging development of quality urban open space system: lessons from the field. University of South Carolina.

4. Mehan A (2016) Public squares and their potential for social interactions: a case study of historical public squares in Tehran. International journal of social, behavioral, educational, economic, business and industrial engineering 10(2): 544-549.

5. Pakzad, Jahanshah (2007) Theories in urban design process. ( $\left.2^{\text {nd }} E d n\right)$. Housing and Urban planning Inc Vol. 2.

6. Zakariya K, Zalina H, Mazlina M (2014) Spatial Characteristics of Urban Square and Sociability: A review of the City Square, Melbourne. Procedia-Social and Behavioral Sciences 153: 678-688.
7. Krier R (1991) Urban Space. Academy editions.

8. Pirnia, Mohammad K (2005) Introduction to Islamic architecture of Iran. Soroush Danesh, Tehran.

9. Zhai B (2014) Definition and Concept of urban square in view of urban spaces and buildings. Bulletin of the Georgian national academy of sciences 8(1): 107-116.

10. Abidin Z, MsUsman I, Tahir Mm, Yap YC (2010) Characteristic of Attractive Square as Public Space: Putra Square, Putrajaya. Topics in Energy, Environ, Sustainable Dev and Landscaping - 6th WSEAS International Conference on Energy, Environment \& Ecosystems and Sustainable Development., EEESD'10, 3rd WSEAS International Conference on Landscape Architecture, LA'10: 338-343.

11. Kevin L (2010) The image of the city. MIT Press, Cambridge.

12. Liu C (2013) Research on scale of urban squares in Copenhagen Master of Science Programme in Spatial Planning with an emphasis on Urban Design in China and Europe. Karlskrona, Sweden.

13. Memluk MZ (2013) Designing Urban Squares. Advances in Landscape Architecture. Sitte C (2006) City planning according to artistic principles. Phaidon Press, Austria 91-112.

14. Tavassoli, Mahmoud, Naser B (2006) Designing urban spaces. Center for architecture and urban planning research, Texa.

15. Abbasian, Armin (2016) Importance of Urban Squares as Public Space in Social Life: A New Design of Fisktorget in Karlskrona City. Blekinge Institute of Technology Karlskrona, Sweden, Europe.

16. Habibi M (2006) Shar Ta Shahr. University of Tehran, Tehran, Iran.

17. Tafahomi R, Hasunddin L, Ahmad B (2007) Transition process of urban spaces in Iran. Post-Graduate Seminar Semester 2 Session: 83-96.

18. Khodabakhshi Z (2014) Structural Elements of Urban Squares from Tradition to Modernity in Iran: A Comparative Study of Isfahan's Naghsh-e-Jahan Square and Tehran's Toop-khaneh Square. Journal of Civil Engineering and Urbanism 4(5): 522-528.

19. Barati N, Elham K (2016) Phenomenological investigation in the event of archetype recognition in Islamic-Iranian architecture (Cases study: 
Toopkhane square, Laleh park, shahzade garden, naqhsh-e jahan square). BAGH-I-NAZAR 13(42): 5-18.

This work is licensed under Creative Commons Attribution 4.0 Licens

DOI: 10.19080/GJAA.2017.01.555574
20. Mohammadzadeh M, Farrokh (2001) Toop-Khane square. University of Tehran, Iran.

\section{Your next submission with Juniper Publishers will reach you the below assets}

- Quality Editorial service

- Swift Peer Review

- Reprints availability

- E-prints Service

- Manuscript Podcast for convenient understanding

- Global attainment for your research

- Manuscript accessibility in different formats

( Pdf, E-pub, Full Text, Audio)

- Unceasing customer service

Track the below URL for one-step submission https://juniperpublishers.com/online-submission.php 